\title{
Impact of Effective Communication on the Quality of Excellent Service and Patient Satisfaction in the Outpatient Department
}

\author{
Dwi Ratna Sari ${ }^{1}$, Dhian Kartikasari ${ }^{2}$, and Nurnaningsih Herya Ulfah ${ }^{2,3}$ \\ ${ }^{1}$ Muslimat General Hospital, Ponorogo, East Java, Indonesia \\ ${ }^{2}$ Department of Public Health, Faculty of Sport Science, Universitas Negeri Malang, Malang, East \\ Java, Indonesia \\ ${ }^{3}$ College of Public Health Science, Chulalongkorn University, Bangkok, Thailand \\ ORCID: \\ Dhian Kartikasari: https://orcid.org/0000-0001-9101-7526 \\ Nurnaningsih Herya Ulfah: https://orcid.org/0000-0002-9339-3493
}

\section{Abstract}

Effective communication is crucial to support nurses in providing excellent service, including a caring attitude towards patients to help facilitate their needs and to realize

Corresponding Author:

Dhian Kartikasari

dhian.kartikasari.fik@um.ac.id

Published: 25 March 2021

Publishing services provided by Knowledge E

(c) Dwi Ratna Sari et al. This article is distributed under the terms of the Creative Commons Attribution License, which permits unrestricted use and redistribution provided that the original author and source are credited.

Selection and Peer-review under the responsibility of the ISMoPHS 2020 Conference Committee. patient satisfaction. The purpose of this literature review was to describe the impact of effective communication on the improvement of the quality of excellent service and patient satisfaction in outpatient departments. This review was conducted by searching published articles on Google with selected keywords including "effective communication," "excellent service" and "patient satisfaction." The search was limited to publications between 2009 and 2019. The result of the study showed that effective communication can significantly impact the improvement of excellent service quality, thereby increasing patient satisfaction with the health care they receive. The study recommends a collaboration between the HR and the Head of Nursing to conduct effective communication training. Nurses are expected to be able to improve their effective communication skills with patients, and further studies are needed to dig deeper into the impact of effective communication on improving the quality of excellent service and patient satisfaction.

Keywords: effective communication, excellent service patient satisfaction

\section{Introduction}

The era of globalization boasts intense competition in almost all sectors, including hospital business which serves to provide health service for its surrounding community. Health service aims to establish health standard that satisfy expectations and the needs of the community by providing effective services [1]. The higher the demands of the community for quality health services, the better the service must be to provide 
satisfaction to clients. Hospitals must be able to meet these needs by increasing the quality of services, by applying customer-oriented or customer-focused strategies.

Outpatient Department as the first entrance in a hospital plays an important role in determining the overall quality of the hospital. If the first impression disappoints a patient, it is likely that they will look for other health care facilities. This will have an impact on the reduction in visit rates. Administrative service factors, location access, cost and facilities, and medical personnel are factors that influence outpatient services. Nurses are medical personnel responsible for the quality of services in hospitals, as patients essentially seek outpatient services to get consultations/opinions from medical staff about their health problems, and whether they need any treatment [2].

One of the important and fundamental aspects in improving excellent service and patient satisfaction is effective communication between nurses. It must be efficient, accurate, complete, clear, and understood by the recipient of the message. Effective communication is one important component in the healing process of a patient that must be maintained by the medical staff. Nurses need to maintain good relations and cooperation with patients, because nurses are the closest people who can comprehend the problems experienced by patients comprehensively [3].

Ineffective communication between nurses and a patient will certainly have an impact on patient dissatisfaction. This will lessen patient trust and loyalty which eventually leads to decreasing number of visits. The result of a cross sectional research conducted by Hanafi \& Richard reports the impact of interpersonal communication on the level of client satisfaction with $(p=0,000)$, claiming that nurses' high interpersonal communication skills with patients will provide satisfaction to them [4]. This result is also supported by Indriyanti's study, which uses the Spearman test, reporting the relationship between nurse communication quality and the level of satisfaction in health services [5].

Additionally, health services require a good quality of service. This is supported by the result of a research by Arianto, stating that creating a good interpersonal relationship is a prerequisite for medical nurses. Numerous studies have shown that successful of nurse-patient communication will have a positive impact on patients, including knowledge satisfaction and understanding, adherence to treatment and measurable health outcomes. The affective quality of the nurse-patient relationship is a major determinant of patient satisfaction and medication adherence [6].

In the world of health increasingly tight with competition, various strategies are needed to generate patient satisfaction. Each hospital seeks for various ways to remain competitive with other hospitals, including by improving the quality of service for patients to provide satisfaction to every customer who uses the products or services of the 
hospital. What can be done to provide satisfaction for patients includes providing excellent service for patients. This is advised by Fatmawati's research, stating that quality health care is needed by the community, and it is highly determined by the health care providing health services at reasonable prices. The success of a hospital cannot be reviewed just from the revenue; the quality must also be considered. When there is quality, the service will be guaranteed to bring customer satisfaction and this is profitable for the hospital. To maintain the loyalty of service users, many hospitals continue to develop quality health care programs to generate patient satisfaction of excellent health services [7].

An excellent service may revolve around the way service providers carrying the duties, which affect patient satisfaction. According to Lassere, creating excellent service does not have to be expensive. Being polite, always smiling, and being friendly to clients do not cost service providers a dollar. Excellent service makes quality and will have an impact on client satisfaction [8]. A research conducted by Dewi et al (2013) found that service quality affects patient satisfaction positively by $99 \%$ [9]. Amin and Nasharuddin in their research also found that by implementing a good quality of service would lead to the service users feeling great satisfaction [10].

Patients usually have confidence in the attributes of a product from the image of the product. Effective communication between the medical staff and patients can increase their confidence in the information provided by the medical staff. Patients' trust and the ability of the medical staff in explaining various information relating to patients' history of illness are included in the factors supporting patient satisfaction. A research by Wahyuni et al. mention several reasons why the patients do not come back to the hospital/clinic where they have been treated: $1 \%$ of them died, $3 \%$ of them states that it is due to relocation, $5 \%$ of them states that they are satisfied with other hospital's/clinic's, $9 \%$ of them states that it is due to competitors' persuasions, $14 \%$ of them states that it is due to dissatisfaction with the hospital's/clinic's products, and $68 \%$ of them states that it us due to poor service quality [11].

Based on the background above, this study focuses on the impact of effective communication on the improvement of the quality of excellent service and patient satisfaction in outpatient department.

\section{Material and Method}

This research uses the literature review method, which is started by searching for articles published on Google Search with the inclusion criteria as follows: (1) effective 
communication, (2) excellent service (3) patient satisfaction. The search was limited to publications from 2009-2019.

\section{Results}

Nurses' ability to perform effective communication is the key to creating a therapeutic relationship between them and patients. It will help nurses in providing excellent service with regard to increasing patient satisfaction with the health services provided.

\subsection{Impact of effective communication on the improvement of quality of excellent service}

Excellent service is in accordance with applicable standards in a hospital, and is the kind that is compatible with patient expectations. Hospitals are the place where multi-disciplinary services may have the potential to overlap one another, cause inter-professional conflicts and delays in examinations and actions [12]. Errors in the implementation of health services (70-80\%) might be caused by poor communication and understanding among the staff. Good teamwork and effective communication can help reduce patient safety problems [13]. Good communication is a strategy to effectively and efficiently achieve the desired quality of results. Communication in collaboration is an important element to improve the quality of service and patient safety [14].

\subsection{Impact of effective communication on patient satisfaction}

Nurses are medical personnel responsible for the quality of services in hospitals, as patients essentially seek outpatient services to get consultations/opinions from medical staff about their health problems, and whether they need any treatment [15]. One of the important and fundamental aspects in improving excellent service and patient satisfaction is effective communication between nurses. It must be efficient, accurate, complete, clear, and understood by the recipient of the message. Effective communication is very important in the process of establishing a therapeutic relationship that can support the healing of patients and protect patients from potential dangers due to miscommunication. 


\subsection{Analysis of the impact of effective communication on the improvement of the quality of excellent service and patient satisfaction}

Effective communication has an impact on the quality of excellent service provided by nurses, and it affects the level of patient satisfaction with the services provided. According to Suwarto, the quality of excellent health services may include perfect performance health staff when giving services. Not only does it generate satisfaction for patients in accordance with the average satisfaction of the population, but also in accordance with established standards and professional codes of ethics. Patient satisfaction is a behavioural reaction after receiving health services. It affects the decision to repeat or re-purchase the same service, and the delivery of messages or impressions to others about the health services provided [16].

\section{Discussion}

The following is the discussion related to the analysis of the impact of effective communication on the improvement of the quality of excellent service and patient satisfaction:

\subsection{Impact of effective communication on the improvement of quality of excellent service}

According to Anita, nurses are required to be able to communicate effectively with other health staff and patients to integrate safe and effective care, which will lead to excellent service for patients. Communication plays an important role in creating quality of services, affecting on patient outcomes [17]. A research conducted by Diane, et al. states that failed effective communication is one of the main causes of sentinel events by $65 \%$, which might result in the decrease in the quality of excellent service [18]. This is supported by a research by Rokhmah \& Anggorowati, stating that effective communication between nurses and the entire healthcare team and patients can significantly improve the quality of excellent service in patient care. Therefore, effective communication must be mastered by nurses to improve the quality of excellent service [19].

A nurse must be able to apply effective communication when taking care of patients. According to Almond P. \& Yardley J., effective communication requires nurses to coordinate well with patients. This study claims that giving a typology ability to work in collaboration with patients is based on egalitarian and ethical principles. To be able 
to do this, nurses need a solid moral framework to help their practice be ethical and sensitive. This framework includes the development and understanding that all patients have the right to obtain good quality health services, to be assisted and facilitated, to eliminate all barriers in order to access good health services [20]. According to Jahromi M. K. \& Ramezanli S., the main barrier in nurses-patients communication is the lack of time to pay attention to the patients' needs. This study also explains the relationship between fatigue, lack of appreciation of the performance of nurses, and the workload of nurses as the barriers to effective communication with patients, thereby reducing the quality of excellent service. Thus, support for nurses is needed to help them improve effective communication with patients to realize excellent service [21].

Effective communication between nurses and patients will affect the improvement of the quality of excellent service. A research by Kurniawati includes 46 respondents (65.7\%) at the Panglima Sebaya Regional Hospital in Paser Regency who repeat their visit. This is the impact of good quality of service supported by therapeutic communication, making the patients in the polyclinic of Panglima Sebaya Regional Hospital of Paser Regency to feel that the treatment at the hospital is successful in curing their illnesses, thus deciding to repeat the visit when they fall sick in the future [22]. Patients will feel satisfied with the services if health staff can establish good relations with them through good communication techniques and attitudes while providing care [23].

Effective communication between nurses and patients will enhance the therapeutic relationship between them so that nurses can provide the best service. EAn excellent service may revolve around the way service providers carrying the duties, which affect patient satisfaction. According to Lassere, creating excellent service does not have to be expensive. Being polite, always smiling, and being friendly to clients do not cost service providers a dollar. Excellent service makes quality and will have an impact on client satisfaction. This certainly will affect one's trust in nurses and in the image of a nurse. Given the important role of nurses in generating patient satisfaction, it is important for nurses to provide excellent service in hospitals [8].

\subsection{Impact of effective communication on patient satisfaction}

Effective communication is the basis for creating interpersonal relationships between nurses and patients by focusing on communicating to understand the emotional response of patients. It is the main method of implementing the care process [24]. The result of a cross sectional research conducted by Hanafi \& Richard reports the impact of interpersonal communication on the level of client satisfaction with $(p=$ 
0,000 ), claiming that nurses' high interpersonal communication skills with patients will provide satisfaction to them [4]. This result is also supported by Indriyanti's study, which uses the Spearman test, reporting the relationship between nurse communication quality and the level of satisfaction in health services [5].

Pujiastuti states that patient satisfaction is affected by nurses' attitudes and behaviour in communication, individual interest and good service delivery. Patient satisfaction is generally about a person's attitude when having an experience in health services. Satisfaction is felt in the mind as it is an emotional condition, with regard to previous experiences, hopes, and social networks. Satisfaction is achieved when patients' perceptions about the quality of health services they receive are positive, satisfying, and meeting their expectations. Eventually, satisfaction at a certain level can lead to patient loyalty. This shows that effective communication by nurses is very influential on patient satisfaction and loyalty to the hospital [25].

Effective communication includes verbal and nonverbal factors. Verbal communication includes words that are clear and easy to understand. Whereas nonverbal communication includes physical appearance, posture, facial expressions, and skin-to-skin interaction. Purwanto, et al. uses a cross sectional approach in their study, focusing on whether there is a relationship between verbal communication and non-verbal communication with patient satisfaction ( $r=0.705, p=0,000)$, with the level of significant of $5 \%(0,000<0.05)$. It can be concluded that verbal communication and non-verbal communication have a significant relationship with patient satisfaction [26]. The result of the study by Gunawan, et al. shows that there is a significant relationship between verbal and non-verbal communication by nurses on the decreasing level of Intensive Care patients' family anxiety [27].

The process of effective communication between nurses and patients is affected by several factors. Tay, et al. shows that the factors affecting effective communication include nurses, clients and the environment [28]. While Suryani claims that psychological and social factors affect communication, including age, gender, cultural background (ethnic and language), social class level, and social role [29]. Patient characteristics include gender, age, occupation, income and economic status, education, and source of fund for medical treatment [30].

Based on a variety of literature, effective communication consists of several important components including: respect, empathy, audible, clarity, and humble, or commonly knowns as the five inevitable laws of effective communication, abbreviated as $\mathrm{REACH}(31)]$. These five conditions are important indicators of effective communication, enabling patients to collaborate with health staff, to improve their own functional and 
psychological status, and to increase their satisfaction with the health services they receive.

Additionally, Kusminarti mentions that another important aspect in conducting effective communication is the attitude of empathy that nurses must have when taking care of patients' needs [32]. A research by Syagitta, et al. states that there are several things to consider in conducting effective communication: the obstacles perceived by nurses when conducting effective communication and effective patterns of nursepatient communication that can affect the level of patient satisfaction with the health services [33].

Patients who are satisfied with the health services provided will be loyal to a hospital. Loyalty encourages patients to repeat visiting the hospital. Patients will feel satisfied if health staff can foster good relations with them through communication techniques and attitudes while providing health care [23]. This is supported by a research by Kurniawati, revealing that there is a relationship between therapeutic communication and the interest in return visits ( $p$-value $=0.013)[22]$.

\subsection{Analysis of the impact of effective communication on the improvement of the quality of excellent service and patient satisfaction}

Implementation of good effective communication can increase the satisfaction felt by patients. Communication plays a very important role in excellent service. Moreover, communication is an absolute necessity for the relationship or interaction between nurses and patients to support their recovery. Interpersonal communication relationship between nurses and patients determines the satisfaction felt by patients. Patient satisfaction is greatly affected by nurses' interpersonal communication when they undergo treatment, as they often compare services among hospitals [34].

Patients' perceptions of the quality of hospital services affect their intention to go to the hospital. This is in accordance with the opinion of Adiwidjaja \& Dhuhaniyati about principles of excellent service quality, including: reliability, responsiveness, assurance, empathy, and tangibility. These principles simultaneously, positively, and significantly affect patient satisfaction [35]. According to Kelana, et al. based on the Spearman Rho statistical test they conducted showing a significance value of $0,000(p<0.05)$, the application of excellent service by nurses affect the level of patient satisfaction [36].

According to Anggarawati \& Wulan Sari, nurses must provide excellent health services. The quality depends on how the nurses take care of the patients and how 
patients feel the satisfaction of the service. A neat outlook, sufficient knowledge and skills, friendly and polite attitude, quick response to the problems of patients, doctors and peers, ability to communicate well, ability to provide convenience, understanding about the needs of doctors in providing services are what the nurses must have when providing health services. Doctors and patients must feel satisfied with their quality of services. This satisfaction is the capital to increase commitment and performance of internal customers (doctors and other health staff), needed to impact on improvement of the quality of customer service (patients and families) [12].

Effective and responsible communication will help nurses to provide the best patient care. In the research by Tjiptono \& Chandra, statistically significant result shows a relationship between nurses' collaboration perceptions and satisfaction with decision making. This is implied by increasing the professionalism of nurses and doctors in providing customer satisfaction-oriented services [37]. Various events can be arranged to improve the quality of services such as excellent service training to improve patient satisfaction with health care. Fong $\mathrm{Ha}$ et al. found a convincing evidence suggesting that when patients feel their nurses are effective communicators, then they will consider them to be technically competent in providing excellent service, and appropriate and effective care [38].

Patients who come to the hospital need medical treatment and a moral support in dealing with and coping with their illnesses, and the psychological impact of it. If someone is sick, they will usually feel anxiety, fear, worry and possible stress to depression. As stated by Chahaal, et al. patients in hospitals show psychological symptoms, especially anxiety and depression, and it will only aggravate the patient's condition. In this case, nurses play a crucial role in effective and empathetic communication to deal with these unfavourable psychological conditions and create a supportive psychological atmosphere to help the patients recover by providing excellent service without eliminating professionalism [39].

The application of effective communication by nurses is needed due to the increasing awareness of nurses about the importance of fostering effective and open communication, to establish a trusting relationship with patients. It will help them understand the patients' problems and properly handle them. Nurses as the front liners of health services need to apply effective communication skills to be able to convince patients that the service they are receiving is of great quality. Hopefully, it can have an impact on increasing patient satisfaction. 


\section{Conclusion}

A hospital is a health service provider. Health services aim to create the standard that can satisfy the expectations and needs of the surrounding community by providing excellent service. The higher the demands of the community for the quality of health services, the better the service must be, to improve client satisfaction. Included in a health service provider team is a nurse. Nurses must have the knowledge of services, good attitude and appearance when providing services to patients. They especially must have the skills needed for effective communication. The application of effective communication between nurses and patients will create a sense of patient confidence in nurses, with regard to their ability to help patients with their health problems. Effective communication can support the development of quality health care programs by providing excellent service. Excellent service in the context of hospital business is provided to patients based on quality standards to meet their needs and desires, to generate their satisfaction, ultimately increasing their trust in the hospital. Effective communication can significantly affect the delivery of excellent service quality, suggesting that it has an impact on increasing patient satisfaction.

\section{Acknowledgement}

None.

\section{Conflict of Interest}

The authors declare that there is no conflict of interest.

\section{References}

[1] Saleha, S. and Satrianegara, S. (2009). Buku Ajar Organisasi dan Manajemen Pelayanan Kesehatan serta Kebidanan. Jakarta: Salemba Medika.

[2] Sumarno, B. A. (2012). Analisis pengaruh kualitas pelayanan jasa terhadap kepuasan dan loyalitas pasien rawat inap di Rumah Sakit St. Elisabeth Semarang. Eksplanasi, vol. 1, issue 1, pp. 1-18.

[3] Roganda, D., Salman, Nurcandrani, P. S. (2016). Pola Komunikasi Interpersonal Teraupetik Dokter Terhadap Pasien Anak roganda. KALBISOCIO, Jurnal Bisnis dan Komunikasi, vol. 2, issue 2, pp. 183-193. 
[4] Hanafi, I., Richard, D. S. (2012). Keterampilan Komunikasi Interpersonal Perawat Berpengaruh Peningkatan Kepuasan Pasien. Jurnal STIKES, vol. 5, issue 2, pp. 15566.

[5] Indriyanti, D. D. (2012). Hubungan Komunikasi Perawat Dengan Tingkat Kepuasan Tentang Pelayanan Kesehatan Pada Pasien Tuberculosis Paru Di Puskesmas Sukodono Sidoarjo. Medica Majapahit (Jurnal IImiah Kesehatan Sekolah Tinggi Ilmu Kesehatan Majapahit), vol. 4, issue 1, pp. 33-45.

[6] Arianto, A. (2013). Komunikasi Kesehatan (Komunikasi Antara Dokter Dan Pasien). E-JURNAL, vol. 3, issue 2, pp. 1-13.

[7] Fatmawati, T. (2016). Pengaruh Mutu Pelayanan Dokter Terhadap Loyalitas Pasien di RS PKU Muhammadiyah Bantul. JMMR (Jurnal Medicoeticolegal dan Manajemen Rumah Sakit), vol. 5, issue 2, pp. 150-6.

[8] Lasserre, C. (2010). Fostering a Culture of Service Excellence. J Med Pract Manage., vol. 26, issue 3, pp. 166-9.

[9] Putri, H. A., Saryadi, S. and Dewi, R. S. (2013). Pengaruh kualitas pelayanan terhadap kepuasan pasien di Rumah Sakit Islam Kota Magelang. Jurnal IImu Administrasi Bisnis., vol. 2, issue 3, pp. 110-6.

[10] Amin, M. and Nasharuddin, S. (2013). Hospital Service Quality and its Effects on Patient Satisfaction and Behavioural Intention. Clinical Governance: An International Journal, issue 18, pp. 238-54.

[11] Wahyuni, T., Yanis, A. and Erly, E. (2013). Hubungan Komunikasi Dokter-Pasien Terhadap Kepuasan Pasien Berobat Di Poliklinik RSUP DR. M. Djamil Padang. Jurnal Kesehatan Andalas, vol. 2, issue 3, pp. 175-7.

[12] Anggarawati, T. and Sari, N. W. (2016). Kepentingan bersama perawat-dokter dengan kualitas pelayanan keperawatan. Jurnal IImiah Kesehatan Keperawatan, vol. 12, issue 1, pp. 44-54.

[13] WHO. (2010). Framework for Action on Interprofesional Education \& Collaborative Practice. Geneva: World Health Organization.

[14] Reni, A., Yudianti, K., and Somantri, I. (2010). Efektifitas Pelaksanaan Komunikasi dalam Kolaborasi Antara Perawat dan Dokter di Ruang Rawat Inap Rumah Sakit Umum Sumedang. Majalah Keperawatan Unpad., vol. 12, issue 1, pp. 36-7.

[15] Sumarno, A. B. (2012). Analisis pengaruh kualitas pelayanan jasa terhadap kepuasan dan loyalitas pasien rawat inap di Rumah Sakit St. Elisabeth Semarang. Eksplanasi, vol. 1, issue 1, pp. 1-18.

[16] Suwarto, S. (2009). Hubungan Kualitas Layanan Dengan Tingkat Pemanfaatan Layanan Kesehatan Dasar Gratis Di Puskesmas Limpasu Periode Juni S.D 
September Tahun 2009 [Karya Tulis IImiah]. Banjarbaru: Universitas Lambung Mangkurat.

[17] Boykins, A. D. (2014). Core Communication Competencies in Patient-Centered Care. ABNF J (The Association of Black Nursing Faculty Journal), vol. 25, issue 2, pp. $40-5$.

[18] Morris, D. and Matthews, J. (2014). Communication, Respect, and Leadership: Interprofessional Collaboration in Hospitals of Rural Ontario. Can J Diet Pract Res., vol. 75, issue 4, pp. 173-9.

[19] Rokhmah, N. A. and Anggorowati, A. (2017). Komunikasi Efektif Dalam Praktek Kolaborasi Interprofesi Sebagai Upaya Meningkatkan Pelayanan. JHeS (Journal of Health Studies), vol. 1, issue 1, pp. 65-71.

[20] Almond, P. and Yardley, J. (2009). Essential Skills Clusters for Nurses: Theory for Practice. UK: Willey-Blackwell.

[21] Kargar, J. M. and Ramezanli, S. (2014). Evaluation of Barriers Contributing in the Demonstration of an Effective Nurse-Patient Communication in Educational Hospitals of Jahrom, 2014. Glob J Health Sci., vol. 6, issue 6, pp. 54-60.

[22] Kurniawati, A. L. (2017). Hubungan Antara Mutu Pelayanan Kesehatan Dan Komunikasi Terapeutik Dengan Minat Kunjung Kembali Pasien Di Poliklinik Penyakit Dalam (Studi Observasi Di Rsud Panglima Sebaya Kabupaten Paser). Jurnal Publikasi Kesehatan Masyarakat Indonesia, vol. 2, issue 3, pp. 116-23.

[23] Akbar, A. P., Sidin, I. and Pasinringi, S. A. (2013). Gambaran Kepuasan Pasien Terhadap Pelaksanaan Komunikasi Terapeutik Perawat di Instalasi Rawat Inap RSUD Labuang Baji Makassar Tahun 2013. Retrieved from http://repository.unhas.ac.id/ handle/123456789/5451.

[24] Betcher, D. K. (2010). Elephant in the Room Project: Improving Caring Efficacy through Effective and Compassionate Communication with Palliative Care Patients. Medsurg Nurs., vol. 19, issue 2, pp. 101-5.

[25] Pujiastuti, W. (2010). Pengaruh Kualitas Layanan terhadap Kepuasan Pengguna jasa Rumah Sakit PKU Muhammadiyah Cepu. Skripsi. Fakultas Ekonomi Universitas Uin Malik Ibrahim. Malang.

[26] Purwanto, D., Anggraeni, T. and Heni, S. (2014). Hubungan Komunikasi Verbal Dan Nonverbal Perawat Dengan Tingkat Kepuasan Pasien Di Instalasi Rawat Inap RSUD Kabupaten Sragen. Jurnal IImu Keperawatan Indonesia, vol. 1, issue 1, pp. 1-12.

[27] Gunawan, A. H. (2018). Analisis Kebutuhan Tenaga Perawat Unit Pelayanan Intensif Berdasarkan Beban Kerja dan Kompetensi di Unit Pelayanan Intensif Rumah Sakit 
Dr Oen Solo Baru Tahun 2015. Jurnal Administrasi Rumah Sakit Indonesia, vol. 2, issue 2, pp. 98-114.

[28] Tay, L. H., Ang, E. and Hegney, D. (2012). Nurses' Perceptions of the Barriers in Effective Communication with Inpatient Cancer Adults in Singapore. J Clin Nurs., vol. 21, issue 17-18, pp. 2647-58.

[29] Suryani, S. (2014). Komunikasi Terapeutik: Teori \& Praktik (2 ${ }^{\text {nd }}$ ed.). Jakarta: Penerbit Buku Kedokteran EGC.

[30] Kusumapradja, R., Suandewi, N. and Germas, A. (2013). Analisis Hubungan Antara Kualitas Pelayanan, Karakteristik Pasien, Dan Hambatan Pindah Dengan Loyalitas Pasien Rawat Jalan RSUD Cibinong. Forum IImiah, vol. 10, issue 1, pp. 64-74.

[31] Suryadi, E. (2010). Analisis Peranan Leadership Dan Budaya Organisasi Terhadap Kinerja Pegawai. Manajerial: Jurnal Manajemen dan Sistem Informasi, vol. 9, issue 1, pp. 1-9.

[32] Kusminarti, R. (2013). Persepsi Tentang Profesionalisme, Komunikasi, Motivasi Kerja, Lingkungan Kerja dan Kinerja Perawat. Retrieved from http://publikasiilmiah.ums.ac. id/handle/11617/5275.

[33] Syagitta, M., Sriati, A. and Fitria, N. (2017). Persepsi perawat terhadap pelaksanaan komunikasi efektif di IRJ Al-Islam Bandung. Jurnal Keperawatan BSI, vol. 5, issue 2, pp. 140-7.

[34] Mirnawati, M. (2013). Hubungan Komunikasi Interpersonal Perawat dengan Kepuasan Pasien Rawat Inap di Ruang Cempaka RSUD AW Sjahranie Samarinda. Psikoborneo, vol. 1, issue 4, pp. 241-9.

[35] Adiwidjaja, I. and Dhuhaniyati, L. (2012). Implikasi Pelayanan Prima (Service Excellence) Dan Paket Agenda Reformasi Layanan Kesehatan: Pelajaran Menarik dari Singapura dan Malaysia bagi Indonesia. REFORMASI, vol. 2, issue 2, pp. 10915.

[36] Kelana, M. T. (2015). Pengaruh penerapan pelayanan prima (excellence) perawat terhadap tingkat kepuasan pasien di Rumah Sakit Universitas Tanjungpura Kota Pontianak. Jurnal ProNers, vol. 3, issue 1, pp.3-12.

[37] Tjiptono, F. and Chandra, G. (2011). Service, Quality \& Satisfaction (3 ${ }^{\text {rd }}$ ed.). Yogyakarta: Penerbit Andi.

[38] Ha, J. F. and Longnecker, N. (2010). Doctor-Patient Communication: A Review. Ochsner Journal., vol. 10, issue 1, pp. 38-43.

[39] Chahal, H. and Kumari, N. (2011). Evaluating Customer Relationship Dynamics in Healthcare Sector through Indoor Patients' Judgement. Management Research Review, vol. 34, issue 6, pp. 626-48. 